\title{
CHASING LIVONIAN HERITAGE ON THE LIVONIAN COAST
}

\author{
Baiba Šuvcāne ${ }^{1,2}$ and Valts Ernštreits ${ }^{1}$ \\ ${ }^{1}$ University of Latvia and and ${ }^{2}$ Kolka's Livonian Centre
}

\begin{abstract}
In 2018, the Livonian cultural space was added to the Latvian National List of Intangible Cultural Heritage, a step towards inclusion in the corresponding UNESCO list. This article seeks to document the present state of Livonian intangible cultural heritage, especially Livonian language, on the Livonian Coast. Currently, this territory is not visually demarcated and is divided among three local governments. This split also can be seen in the display of information. Signs and displays use Livonian, but their quality should be improved. Though the Latvian State Language Law states that Livonian and Latvian names can be used together on the Livonian Coast, no official bilingual signs exist. Tourism business operators rarely use Livonian heritage in their offerings. Community organisations have been more active in this regard. At their events, one can become acquainted with the cultural heritage of this region and hear Livonian.
\end{abstract}

Keywords: intangible heritage, language documentation, language environment, linguistic landscape, Livonian

DOI: https://doi.org/10.12697/jeful.2018.9.2.05

\section{Introduction}

The Livonians are a uniquely important and integral part of Latvia's cultural heritage. The roots of Livonian cultural heritage stretch far into the distant past. Despite the fact that for many centuries the Livonians have been subject to ethnic and linguistic assimilation, wars, and also the Soviet occupation, somehow we have managed to keep our language and culture alive. We have enriched it, developed it, nurtured it.

In the present day, Livonian cultural heritage is protected by Latvian state law. The law "On the Free Development and Right to Cultural Autonomy of Nationalities and Ethnic Groups in Latvia”. (Par Latvijas nacionālo un etnisko grupu brīvu attīstību un tiesībām uz kultūras autonomiju) went into effect on March 19, 1991. This law states that the Latvians and an ancient indigenous nation - the Livonians - live in the Republic of Latvia. However, Article 4 of the law states that the 
national government and administrative institutions of the Republic of Latvia are responsible for the preservation of the national identity and cultural historical environment of Latvia's ancient indigenous nation the Livonians - as well as ensuring the restoration and development of the socioeconomic infrastructure of their inhabited territory. Article 4 of the Latvian State Language Law guarantees that the state ensures the preservation, defence, and development of the Livonian language as an indigenous (autochthonous) language of Latvia. Likewise, Article 18 Paragraph 4 explains that place names on the Livonian Coast as well as the names of institutions, community organisations, businesses, and events occurring within this territory are to be formed and used in the Livonian language. This final point is supplemented by the Place Name Information Regulations published on January 10, 2012 where Paragraph 7 states "The place names of the territory historically inhabited by the Livonians are to be formed in the Livonian language and according to Livonian language norms." The Livonians are also included in the Preamble of the Constitution of the Republic of Latvia and in the Latvian Culture Canon.

One of the places where Livonian cultural heritage can be encountered in its most concentrated form is in the Livonian fishing villages of northern Courland (Latvian: Kurzeme), also known as the Livonian Coast, as it has usually been called in more recent times. There are 14 villages traditionally considered to be part of this region, which are found along the coasts of the Baltic Sea and the Gulf of Riga: Oviši (Livonian: Pațīkmō), Lūžņa $(L \bar{u} z \bar{z})$, Miḳeḷtornis (Pizā), Lielirbe (İa), Jaunciems ( $\bar{U} z \overline{k i l a})$, Sīkrags (Sīkrõg), Mazirbe (Irē), Košrags (Kuoštrõg), Pitrags (Pitrõg), Saunags (Sä̈nag), Vaide (Vaid), Kolka (Küolka), Melnsils (Mustānum), Giipka (Gipkõ). In this region, the Livonians still lived as a compact community until the 19th and 20th centuries, using Livonian as their language of daily interaction.

\section{Background}

During the last decade, the number of tourists visiting the Livonian Coast has greatly increased. Some role in this has been played by the paving of the entire length of the Kolka-Ventspils road in 2011. However, people mostly come to this place, wishing to encounter something Livonian in the still recently little-known Livonian seashore and its coastal villages. 
The elements of Livonian heritage - both tangible and intangible found on the Livonian Coast, has been described in many publications. In the last decade, an entire string of books has been published devoted to the Livonian Coast as a whole (Šuvcāne xxx, 2018), its individual villages (Šuvcāne 2002, 2006, 2010, 2012, 2015, 2017), various types of intangible heritage (Blumberga et al 2013; Ernštreits 2010; Šuvcāne 2003) as well as publications used in connection with tourism (LB; Ernštreits 2017; etc.).

Currently, the Latvian and Estonian cross-border project "UNESCOtourism" is being enacted and one of its goals is the popularisation of Livonian intangible heritage. Representatives of Livonian community organisations and local governments as well as the association "Lauku ceļotājs" (Rural traveller) are cooperating on this project.

All of the preconditions exist to make the Livonian heritage of the Livonian Coast one of the main elements attracting travellers to this region. But, how noticeable even is Livonian heritage on the presentday Livonian Coast?

On November 8, 2018, the Livonian cultural space - the entirety of the elements of Livonian intangible heritage - were added to the Latvian National List of Intangible Cultural Heritage. This also marks the beginning of the journey for the present-day Livonian community towards inclusion in the UNESCO List of Intangible Cultural Heritage. The current article is based on the study which gathered information about Livonian heritage so that the Livonian cultural space could be included in this list. Its goal was to document the current state of the Livonian Coast from the perspective of Livonian intangible cultural heritage. This was accomplished by visiting all of the Livonian Coast villages and documenting the situation, which could be observed there.

The authors themselves are active researchers of Livonian heritage who have deep knowledge regarding various Livonian cultural monuments found on the Livonian Coast and about the connection of places on the coast with Livonian cultural history. However, in this article, attention is given to gaining a different kind of impression of the Livonian Coast by playing the role of a traveller arriving on the Livonian Coast in the present day without any background knowledge, without using the services of tourist information centres or guides, but still wishing to learn about the Livonian language and Livonian heritage, and possibly coming in contact with actual Livonians for the first time. Special attention is paid to the use of elements of language in the linguistic landscape of the Livonian Coast, as language is emphasised in 
the application for inclusion in the Latvian National List of Intangible Cultural Heritage as being the central element of the Livonian cultural space which is present in all modern Livonian cultural processes. As a result, language should be quite noticeable also in the historical territory of the Livonians.

\section{A Journey through the Livonian Coast villages}

Regardless of which road a traveller chooses to take when venturing to the Livonian Coast, they will not know when they have arrived and will not be able to take a photograph of when they have crossed the "border". In the 1990s, when the state protected Livonian cultural historical territory "Līvõd rānda" still existed, wooden signs had been placed on all of the major roads, which identified this territory not only on the map, but also within the visual field of travellers. However, these signs have long since disappeared, which leaves one to hope that a traveller will at least be able to sense their arrival in the cultural historical territory of the Livonians by driving into the first village.

Arriving on the Livonian Coast from the direction of Ventspils, the first village is Oviši. Nowadays it is only sparsely inhabited and the main centre of the village is the Oviši Lighthouse complex. The lighthouse tower is a national industrial monument. Oviši Lighthouse has become a popular tourist destination. The lighthouse complex contains a small exhibit about the history of Latvian lighthouses. Walking around the village, there is no indication of its Livonian heritage. However, if there were an informational display at the historical home of the Princis (Livonian: Prints) family, travellers would learn that Kārlis Aleksandrs Princis was born and had grown up there. Princis was a world famous entomologist and one of the most well-known members of the Princis family who were of great significance to Livonian cultural history. If one happened to stop at the Oviši cemetery, then the long line of graves of members of the Princis family would be immediately noticeable. The grave of the family patriarch, Indriksis, is quite prominent. However, there is no place in the village where one sees its Livonian name - Pați kmo - which would testify to the historical presence of the Livonians in this village.

The next village is Lüžņa. These days it is difficult to call it a village, as it consists of just a few inhabited houses. Attached to a large, preserved building, one encounters a sign reading "Lūžņa station 
1916-1962" (Lüžñas stacija 1916-1962) written in Latvian. In the seashore dunes there are two small border guard shacks, which are proudly adorned with a sign in Latvian reading "Private Property". There are a couple of fishing boats on the beach, which suggests that someone here is still fishing. However, there is nothing in the village indicating that the Livonians had ever lived here. There is no sign at all of Livonian heritage in this place.

A gravel road leads from the highway into the centre of the village of Mikseltornis. Here one finds a church, a lighthouse tower, and an ancient, interesting, preserved building, on which one sees a plaque with the year "1853" inscribed on it. Not far from there are signs pointing the way towards the "Miķel̦bāka" campsite and the "Prinči" guest house. Walking around the village, it appears that there is no sign of Livonian heritage here either. However, an observant traveller will notice a Livonian flag flying from a house sitting in a hollow among the dunes and will notice a vacation house with the Livonian name for Mikseltornis Pizā - written on it; however, they may associate that not with the Livonians, but with the famous city in Italy. Visiting the cemetery, the traveller's attention will surely be drawn to the memorial monument dedicated to the Livonian poets born in Miķelstornis and with Livonian poetry inscribed on it in Livonian and Latvian. This is the first monument constructed in honour of the Livonians. It also conceals within it the story of the Livonians' quiet resistance to the Soviet regime in the 1970s, though there is nothing there to help a traveller learn this story. And it is doubtful that a traveller will find the memorial stone at the grave of Ulıi Kīnkamäg - a Livonian poet at one time referred to as the "Livonian king" - or the cross marking the resting place of one of the first Livonian and Latvian poets - Jānis Princis, Jr.

Travelling onward, the map indicates that after crossing the Irbe River, one should find the village of Lielirbe. But - where is it? There are no signs marking its location. Driving down one side road, one finds themselves by a couple of houses and the cemetery, driving down a different one - more houses, also access to a campground and tourist boat landing. Turning off of the highway before the Irbe bridge, one can find an old border guard post, which still contains a sign stating that the Soviet border is sacred and inviolable. Next to a building with the name "Randa" is a sign indicating that this was the location of the Lielirbe train station. Just nearby in a large meadow one finds a large wooden cross. This was the location of the Lielirbe Baptist Prayer House, which, in 2011, was moved to the Ventspils Seaside Open-Air Museum, but 
how can anyone passing by learn about any of this? If one looks very carefully, one can find the former location of the old narrow-gauge railroad bridge across the Irbe River. It is marked by a pedestrian bridge hung from cables, though presently it is not safe to use for crossing the river. Whether a traveller will even notice what was once one of the largest Livonian Coast villages is entirely dependent on their own observation skills. No sign of this village's Livonian heritage is to be found there at all anymore.

In Jaunciems, as well, there is no evidence of the Livonians' presence, and there is only one farmstead, which is actually inhabited here. But, at least on the highway there is a sign pointing the way to Jaunciems.

Continuing the journey up the highway towards Kolka and crossing the small Ķikans River, we arrive in Dundaga Municipality. Soon a sign appears showing where to turn for Sīkrags village. The road leads to the village centre and here we find an attractive informational display in a clearing where one can read basic information about the history of the village - also in Livonian. There is a map of the village. And just nearby, a bench on which to sit down. The place for this display has been chosen well, as its position offers an excellent view of the village's historic centre. Across the way there is a new building built in a traditional style. Next to it is a sign indicating that the residential house at Kilasidami homestead was built in 1892. This sign is somewhat confusing, however, as the building next to it has clearly been built only recently. Next to a few of the other buildings in the centre of the village there are also similar signs with information in Latvian and Livonian. Nearby on a small hill, a traveller will find the old village cemetery with some gravestones dating to the 19th century. The map and its information provides the opportunity to get to know the village a bit and to finally understand that one has arrived in an old Livonian village.

A few kilometres further in the direction of Kolka, the traveller will find themselves at a crossing where they will have to choose whether to go to Dundaga, the main town in the municipality, or to turn down the road on the left, which goes to the central part of Mazirbe village. The beginning of this area is marked with a large, white two-story building characterised by its unique architecture. This is the Livonian Community House and outside of it there is a Livonian flag flying. The black granite plaques by the entrance announce in five languages - with Livonian among them - that this building was built by the Livonians with the help of their kindred nations and their homeland, Latvia. During the 
summer season, a traveller can go inside the Community House and see the interesting and valuable exhibit about the Livonian coastal villages, listen to the guide from the Livonian Union talk about the history of the Community House, the Livonians, and Mazirbe. There is also tourist information there and copies of the annual Livonian yearbook. Inside of the Community House there is the pleasant "Dižjūrina" (Great Sea) cafe where, among the offerings on its menu, the traveller will find fish dishes characteristic of the Livonian Coast with the menu itself also written in Livonian.

Visitors can read about the history of the village of Mazirbe in Latvian, Livonian, and English on an informational display located by the Livonian Community House. Green signs in Latvian and Livonian point the way to different landmarks and places in the area. Next to them is an informational display in English and German about the Community House. If travellers happen to be in Mazirbe on the first Saturday of August, they will find themselves at the most significant annual event on the Livonian Coast - the Livonian Festival organised by the Livonian Union. This festival brings together not only the residents of the coast, but also many guests from across Latvia as well as from other related nations abroad.

If one chooses to follow the signs and visit the part of Mazirbe where the church, plague stones, and old cemetery are located, one will find these landmarks, but will learn nothing about the unique plague stones. They also will not learn that just nearby was the famous Irbe inn. They will not see the werewolf's grave, which many wish to find the old Mazirbe cemetery. They will not learn any information about the only grave monument in the cemeteries on the Livonian Coast with an inscription in Livonian and English.

It is only four kilometres along the forest road between Mazirbe and Košrags. One can read about Košrags village and the Livonian Coast on an informational display located in the centre of the village near the Valdamo household. There are signs identifying the older village homes as well as information about the history of these homes. Near a building constructed in modern times, but clearly still quite old, there is a sign reading: Žoki, Anno 1743. A walk around this small village shows that the traditional Livonian fishing village construction is well preserved. An observant individual will notice that in small Košrags, more so than in the other coastal villages, there are more homesteads with Livonian names: Valdamo, Alabi, Kūvali, Eļmi, Virgo, Norpiedagi, Kōrand. They will also notice that there are Livonian flags flying next to some houses 
on an everyday basis, but also that the owner of Rotkali household has placed in the large yard of the property a fishing boat painted in the colours of the Livonian flag: green, white, blue.

Following the signs, it is possible to make one's way to the neighbouring village of Pitrags along the forest road instead of the highway. The Košrags-Pitrags cemetery is located halfway between the two villages. On the Košrags end, one can find the grave of Livonian culture worker Didrikis Volganskis. This appears to be one of the few grave monuments found in the Livonian Coast cemeteries, which provides information about a person's work relating to Livonian culture. The cemetery also contains the grave of Marija Šaltjāre who was another prominent person relating to Livonian culture and also a folklore consultant; however, only someone who knows where to look will find it. The road winds along the bank of the Kukšupe, or Pitragupe, River, then crosses it, and takes one into Pitrags village. Also here, there is an informational display in the centre of the village where one can read about the history of the village in Latvian, Livonian, and English. Similar displays are also found in the next villages - Saunags and Vaide. Signs are placed to help tourists find the way to the sea, to the Pitrags Baptist Church, to the campground "Pie Andra Pitragā", to Saunags. It may be especially tempting for travellers to visit "Pie Andra" once they see smoke rising from the smokehouse located in the yard of the property. However, the church can only be visited on Sundays.

The journey onward to the neighbouring villages of Saunags and Vaide can be continued along the forest road. In order to get better oriented in Saunags village, the traveller will almost certainly take a look at the map on the informational display and, possibly, think what unique names homesteads have in this ancient Livonian village: Tullamori, Taliskeri, Grapas... Are these in Livonian? Or perhaps these are the places where Livonian whiskey and liquor are made? The fact that Livonian heritage is still celebrated in this village will be clear to the traveller from the Livonian flags, which are flown every day from the masts by various homes. Giving a wave to the unique attractions there - the large brightly-coloured duck, for example - it is possible to make one's way to Vaide village by passing through the Dižsaunags part of the village.

Entering Vaide from the direction of Saunags, a traveller will not find an informational display, but will instead notice a sign pointing the way to the Antler Museum. It would also be difficult to see much of the villages as the houses are hidden by the forest. Following the sign 
showing the way to the Vaide cemetery, one will notice a large grave stone in one corner with the Livonian inscription Zūonkõ aim kālmad (the Zūonkõ/Žonaks family graves). Another half kilometre beyond there, the traveller will find themselves at Vaide Pond and Vecročupe River. Here they will also find an informational display, a gazebo, and a car park.

To get to Kolka from here, one has to take the highway. Every traveller going to Kolka, will first make a stop at Cape Kolka. This is the most popular spot on the entire Livonian Coast and welcomes approximately 60,000 visitors every year. This area has been laid out and contains facilities making it is suitable for tourists, it contains displays with information about Slitere National Park, Cape Kolka, the border zone. Livonian is also used here and there on signs. The greeting displayed on the outside of the information centre welcoming visitors also appears in Livonian. On holidays and other important occasions, the Livonian flag is flown from its tall mast. It is possible to purchase various informational booklets, maps, and souvenirs at the centre. There are even a few souvenirs with some Livonian design elements. In Kolka, the cafe "Divjūriņas" (Two seas) is open during the summers. Just like at its affiliate cafe "Dižjūriņa" at the Livonian Community House in Mazirbe, its logo and the design of its menu incorporate the greenwhite-blue Livonian colours. Likewise, its menu also contains the name of each dish in Livonian. Travellers will find fish dishes characteristic of this part of the coast on offer at the cafe.

Presently, Kolka is the largest Livonian Coast village and also the only one which continued to develop during the Soviet period and in a situation characterised by the isolation imposed on the region given its status as a border zone. Arriving in the centre of Kolka, a traveller will notice a two-story building with a Livonian flag flying outside as well as a sign reading "Līvu centrs Küolka" (Livonian Centre Küolka). The centre has information available about the Livonians and one can acquaint themselves with various publications in Livonian and Latvian, watch movies in video and DVD format, listen to Livonian consultants, Livonian songs, and also recordings of Livonian language samples. Livonian household items, tools associated with fishing and fish processing, handicrafts, information about the history of the village are all on display. Over the years, visitors from every continent have visited the Livonian Centre Küolka. Tourists can find the summer opening hours posted on the door. Beginning in 2019, the centre will be located in a new space in the Kolka Livonian meeting house. 
Kolka is the only village in Latvia where the Livonian and Latvian flags fly alongside each other outside of the local government building. The Kolka Parish coat of arms contains the colours of the Livonian flag testifying to the Livonian connections of this area. It displays the triangular shape characteristic of Cape Kolka on a sea-blue background and a small shield in the centre with the colours of the Livonian flag - green, white, blue. The Dundaga Municipality flag and coat of arms also use the Livonian flag colours.

Melnsils is located 14 kilometres away on the highway in the direction of Riga. Presently, it is the second largest of the northern Courland Livonian Coast villages after Kolka. Walking around the village, the traveller will be surprised by the new construction. Melnsils contains more summer homes constructed according to a variety of architectural styles than any of the other villages. It has almost entirely lost its earlier fishing village character. There are no Livonian features or related information to be found here.

The traveller only still has to take a look at Gipka and they will have gone through the entire Livonian Coast. Giipka, much like the other coastal villages, comes to life during the summer. This is the location of the guest house "Klettnieki", which is much beloved by travellers and which offers a wide variety of options for relaxation. Presently, there is no hint any longer that the Livonians once lived in this village. Not far from Gipka, on the bank of the Pilsupe River about 500 metres before the spot where it flows into the sea, is the Pürciems settlement or the White Dune (a national archaeological monument with state protection number 2251; ref). This is the oldest evidence of the existence of possible ancient ancestors of the Livonians having lived on the Livonian Coast. According to archaeologists, during the Stone Age (Neolithic) people lived in settlements here and the evidence remaining of their material culture can be linked to ancient Finno-Ugric tribes.

If a traveller wishes to become acquainted with the Livonian Coast from the direction of the sea, by travelling the distance between Lūžņa and Melnsils on foot along the beach, they will have difficulty in finding the paths to each village. The fact that there is a Livonian village beyond the dunes would occasionally be evidenced by the presence of a boat on the beach or the remains of an old pier. They would not, of course, pass by Cape Kolka and Kolka without recognising them; however, the presence of the other villages along the beach is difficult to perceive. More than ten years ago, the Livonian Union put up large signs on the beach with text in Livonian and Latvian identifying the location of the 
villages. These can still be seen in some spots, though these certainly need to be renewed.

\section{Maintaining and popularising Livonian heritage on the Livonian Coast}

Let us examine the Livonian Coast from a different perspective, namely, how do local residents and Livonian Coast tourism businesses preserve, protect, and popularise Livonian heritage. Despite the fact that Latvian is now used as the language of communication on the Livonian Coast, that the earlier traditional way of life has changed, and that the population has noticeably decreased, even so the indigenous inhabitants and their descendants have maintained a sense that they belong to a different ethnicity. And not only that awareness, but also the desire to display marks of Livonian identity in everyday life. First and foremost, this is the Livonian flag, which appears increasingly often on the Livonian Coast not only during holidays, but also just in everyday life. It was pleasant to see in 2016 on a regular July day in Saunags, the Livonian flag flying next to several homes. "We are proud that our ancestors were Livonians and want the flag to always remind us of our roots," explained the resident of one home. Livonian flags are also appearing increasingly often by the homes of new residents. The colours of the Livonian flag have become a sign by which Livonians identify themselves, which not only residents of Livonian descent try to use, but also other people on the coast who wish to show their respect for the preservation of Livonian identity, their connection to this coast, and their wish to support and pass on the green-white-blue colours are encountered ever more often. These colours appear in tourism information booklets and informational displays, on vacation houses at Cape Kolka, in logos, in flower arrangements presented at celebrations, in candle displays, table decorations, and handicrafts.

Individuals operating tourism businesses on the Livonian Coast are also endeavouring to acquaint visitors with Livonian heritage. It is possible to relax, conduct seminars and creative workshops at the vacation house "Pizā" in Miķeļtornis. A wide array of Livonian literature is available. The Livonian flag holds a place of honour.

The vacation house Stūrīši - Branki in Mazirbe offers guests a place to stay, delicious meals as well as provides them with an introduction to Livonian history and Mazirbe village as well as exhibits a collection of both older and newer household items. 
Visitors who wish to experience and learn about nature as well as enjoy peace and quiet come to the guest house and campground "Pìtagi" in Košrags. Various community and thematic events take place here. A small library has been assembled in which visitors can also find publications about the Livonians.

"Pie Andra Pitragā" offers accommodations in vacation cabins or at their campground and also gives tourist groups the opportunity to sample and purchase smoked fish. Visitors always enjoy the owner's knowledgeable descriptions and absorbing stories about the traditional methods for preparing fish on the Livonian Coast. There is also something else unique to see here - Livonian fences. These are 27 different sections of Livonian Coast fences, which have been constructed according to information in ethnographic materials. This fence display is the only one of its kind in Latvia. In 2015, this homestead was presented with the cultural award "Latviskais mantojums" (Latvian heritage) for preserving and promoting the cultural heritage of the Livonian Coast.

The main object of interest in the smaller village of Vaide is the Antler Museum (Ragu muzejs) at Purvziedi homestead where one can learn many interesting facts about Livonian Coast fauna as well as relax at the lovely Purvziedi campground.

As noted earlier, the most visited spot on the entire Livonian Coast is Cape Kolka. Cape Kolka is managed by SIA "Kolkasrags", which organises and supports culture and education projects as well as popularises the cultural history, national values, local traditions, and the environmentally-friendly lifestyle of the Livonian Coast. In the present day, Cape Kolka has become a national as well as international attraction.

Tourists can become acquainted with Livonian culinary heritage at the Kolka vacation house and campground "Ū̌ši" (Kolkas brīvdienu mäja - kempings "Uši which carrot pies (Livonian: sūrkak, sklāndakak, Latvian: dižrausis, sklandarausis) are prepared, which are a traditional food of northern Courland. They also offer tourist groups the chance to try a traditional variety of barley and potato porridge (Livonian: sandrok, Latvian: bukstinbiezputra) and carrot pies. There is literature available about Livonian history and culture and it is possible to rent bicycles to explore the surrounding area.

The Livonian language is rarely heard now on the Livonian Coast. However, one can encounter it in songs performed by ensembles and choirs, at various events organised by community organisations like Lìvõd $\bar{I} t$ (the Livonian Union) and Lìvõ Kultūr sidām (the Livonian 
Culture Centre) such as the Livonian Festival, the summer camp for children and young people of Livonian ancestry, and the International Livonian Summer University. The language is kept alive also by younger members of the community of Livonian descendants who have learned Livonian.

The authors' experience during the last decade shows that the Livonian Coast, the Livonian language, and the fate of the Livonians in past and present times was attracting increasing attention from not only tourists, but also representatives of various interest groups. The Livonian Coast has been visited by researchers, students, journalists, filmmakers, presidents, ambassadors, and businesspeople from Latvia and other countries. A visit to the Livonian Coast was awarded as a prize to the winner of a literature contest in Spain for Basque young people. In 2015, the Livonian Coast was the location for the second Festival of Finno-Ugric Culture. In 2017, the participants of the Estonian modern theatre programme LATEST came here for inspiration. They created an exhibit in honour of the centenaries of Latvia and Estonia - a new work about the Livonians "Pirmie, kas aiziet" (The first to leave), which was first exhibited on February 15, 2018 in Rīga.

Long and short stories for television programs, internet portals, newspapers, and magazines have their origins on the Livonian Coast. The coast has been filmed by the Poles, the French, the Germans, the Finns, the Estonians, the Russians, and others. Though it should be noted that foreign filmmakers sometimes view the Livonians as an exotic addition to the natural beauty of the coast.

It can certainly be claimed that interest in the Livonians, their history and language, about the possibilities for further development in the present and future have not disappeared, but instead have only grown. Therefore, it must be seen to that Livonian heritage is easily accessible, clearly visible, compelling, and comprehensible to anyone who is interested in it.

\section{Conclusions}

We have finished our journey down the Livonian Coast. What conclusions can we draw? What aspects of Livonian heritage do we find and not find? Our first observation: a bit of a paradox has developed where we know where the Livonian Coast is, but we cannot see where it is. In the 1980 s this territory was not yet called the Livonian Coast. 
Traditionally, it was the Livonian seashore with the 14 Livonian fishing villages we already have mentioned. The concept of the Livonian Coast came about in the early 1990s when the state protected Livonian cultural historical territory "Līvõd rānda" (Livonian Coast) was established, the borders of which extended from Ģipka to Oviši and which was shown on the map. This territory came to be referred to in conversation as the "Livonian Coast". Since 2003, when Lìvõd rānda ceased to exist, the territory no longer has any administrative boundaries. In the present day, the Livonian Coast is a territory which is not marked off visually and which everyone imagines differently. For one person it begins in Oviši and ends in Ģipka, for another it starts in Lüžņa and extends to Melnsils, and for yet another person it is the territory between Mazirbe and Kolka.

However, there is one element that does make it possible to see and feel that one is on the Livonian Coast: the Livonian flags which have begun to commonly appear next to many homes in the Livonian villages during the last ten years. If in the 1990s Livonian flags were used mainly at Livonian events (at the Livonian festival, summer camps, and so on) or individual buildings in the historical fishing villages, symbolising the fact that the event participants or the building owner are members of the Livonian community, then in the mid-2000s they began to appear elsewhere, now characterising the historical Livonian territory. This tradition has spread widely also among permanent and seasonal residents whose only connection with the Livonians is the fact that they own property on the Livonian Coast.

Our second observation: the Livonian Coast is currently divided between the territories of three different municipalities. The coast from Oviši to Jaunciems is in Tārgale Parish within Ventspils Municipality. The villages from Sīkrags to Kolka are in Kolka Parish within Dundaga Municipality. Melnsils and Ģipka are in Roja Municipality. Currently, Oviši, Lūžña, Lielirbe, and Jaunciems have few residents, and no Livonian-related activities take place there. In more recent times, it has been hard to see any signs of Livonian identity in Melnsils and Giipka. Livonian heritage has been kept alive and popularised primarily by Dundaga Municipality. At this time, a traveller to the Livonian Coast will not perceive the coast as a unified whole. Oviši, Lūžņa, Miķeļtornis, and Lielirbe in Ventspils Municipality as well as Melnsils and Ģipka belonging to Roja Municipality remain apart and the opportunities to appeal to travellers by invoking the Livonian heritage of these villages are not being used at all. 
This split between administrative units can also be seen in the differences in the display of information. These displays primarily give information about individual Livonian villages, or even just individual sights, rather than about a unified historical Livonian territory. This approach keeps travellers from having an overall understanding and sense of Livonian heritage across its entire historical territory; also, because no basic information is provided about who the Livonians are, how they are unique, and why this part of Latvia is called the "Livonian Coast".

This division, of course, also has practical reasons. First of all, the tourist infrastructure in this territory is constructed by various state, local government, community, and also private institutions. However, the work local governments do relating to such projects happens only within the territory overseen by that local government. The result of this can be seen in considerable differences in tourist infrastructure.

It is clear that without ongoing coordinated cooperation between all three local governments it is not possible to identify the Livonian Coast as a unified historical territory, nor is it possible to fully take advantage of the potential offered by the inclusion of the Livonian cultural space into the Latvian National List of Intangible Cultural Heritage.

Our third observation: signs showing the way to particular sights and places as well as informational displays providing information on a particular village are found primarily in the coastal villages of Dundaga Municipality - in Ventspils and Roja Municipalities they practically do not exist. Though, even in Dundaga Municipality, there are a number of objects which are important to the preservation of Livonian heritage, but about which there is no information or signs identifying their location. It is a positive development that the informational displays and other signs also use the Livonian language. However, it should be noted that the overall quality of the information in the displays and other signs placed by different homes should be improved. There is an absence of information about Livonian culture workers in the villages. For example, passing by Ķesteri household in Mazirbe, someone who does not know so already, will have no idea that the excellent Livonian poet, translator, and culture worker Kārlis Stalte lived here nearly his entire life, and also that this was the location of the editorial board for the "Livli", the only newspaper ever published in Livonian. There is no shortage of such examples.

These signs also, possibly, are associated with the most important as of yet untapped - possibility for identifying the Livonian Coast. 
Namely, all of the existing signs and informational displays, which feature text in Livonian (in the villages of Dundaga Municipality, Cape Kolka, and elsewhere), have come about as a result of small projects or private investors. These signs are of various types, primarily local, and visible quite close to the actual object that they identify - in village centres or in other secondary places.

However, as mentioned in the introduction, within the geospatial environment of Latvia, Livonian is subject to a unique exception in the Latvian State Language Law. According to the State Language Law, place names as well as the names of institutions, community organisations, businesses, and events taking place in this region may be create and use in Livonian alongside Latvian. The Place Name Information Regulations published by the Cabinet of Ministers of the Republic of Latvia clearly state that place names in the territory historically inhabited by the Livonians are to be created also in Livonian observing Livonian language norms. Though the State Language Law has been in effect since 1999 and the Place Name Regulations were published in 2012, up until the present, no official bilingual road signs, signs pointing the way to cultural monuments or natural sights, signs at public transportation stops or at institutions have been installed, which would show the name of the place or object in Livonian alongside Latvian. However, it is precisely the use of Livonian on official signs and in names, which could not only help in visually demarcating the Livonian Coast and allowing travellers to feel that they have arrived in a different cultural space, but also to directly encourage them to seek out and learn more about this culture and language.

Our fourth observation is associated with the use of Livonian heritage in tourism. There are few individuals with tourism-related businesses on the Livonian Coast. There are still too few places to spend the night or have a meal, and this continues to become more problematic as the number of visitors to the Livonian Coast increases and the fact that tourism to the coast is no longer linked to the beach season.

However, one can see that individuals with tourism-related businesses are shy about utilising Livonian heritage in their offerings. The main attraction offered to tourists is having a quiet place to relax by the sea. The opportunity to learn about Livonian heritage is either not offered at all or is assigned a secondary position. Even when a particular tourist package is closely connected with the Livonians (for example, carrot pies or fishing and fish preparation traditions), the connection with the unique coastal culture of the Livonians is not highlighted. Even 
on the websites of the most visible Livonian Coast tourism businesses, there are few if any mentions of the Livonians and opportunities to become acquainted with Livonian culture are practically not offered.

\section{Looking towards the future}

The present moment is very favourable for making the Livonian Coast more attractive to every traveller - to make it not only a beautiful place to relax by the sea, but also to offer every visitor to this territory the opportunity to learn about, understand, enrich their knowledge about Livonian heritage, which is a key part of Latvia's national cultural heritage.

At this time, the work necessary for the inclusion of Livonian cultural heritage into the Latvian National List of Intangible Cultural Heritage has concluded. This is an intermediate stage on the way to the inclusion of Livonian cultural heritage into the UNESCO List of Intangible Cultural Heritage. However, the actual situation shows that in the historical Livonian territory - the Livonian Coast - much still must be done for it to become a place where one can be come acquainted with this heritage.

Visually identifying the Livonian Coast - with markers at its historical boundaries, with signs including both Livonian and Latvian names, with Livonian flags - would be the first significant step for ensuring that anyone visiting this territory understands, feels, and considers the fact that they have arrived in a different cultural space.

The Livonian language is one of the primary components and movers of Livonian cultural processes. The element of language stands alongside everything. Regardless of whether it is the Livonian Festival, singing in Livonian, or place names or other names. The restoration of the presence of Livonian place names, village names, road signs, the names of different sights, rivers, and other noteworthy places in nature in Livonian. These would be unmistakable indicators that a traveller has arrived in a different cultural space. It should be noted that after years of waiting, it seems that this year this process has finally been set in motion, as the local governments of the Livonian Coast have begun to speak about establishing this type of system of Livonian signage.

The construction of new informational displays in every village, which would provide high-quality information in Latvian, Livonian, and English about the history of that village, its existing Livonian heritage, 
and its significant community and cultural figures would be important for the identification and highlighting of Livonian heritage. The village map could contain not only the names of homes, but also show the specific connection of each home with Livonian cultural figures and events. It would be useful to have small informational displays placed at the old and modern cemeteries on the Livonian Coast. In order for these elements of Livonian heritage to be easy to find, it would be important to place informative signs with a unified design and text in Latvian and Livonian in the villages. And, of course, a Livonian flag should be flying in the centre of each village.

The people of the Livonian Coast - first and foremost the owners of tourism-related businesses - should think more about how to use Livonian heritage to attract visitors. This process could be started with just a few smaller efforts. Good examples of this are SIA "Kolkasrags", which has a website partially available in Livonian, and also the owners of the cafes "Divjūriņas" and "Dižjūriņa", who have sought to include typical Livonian foods on their menu as well as to translate the menu into Livonian.

A meaningful contribution to the study, understanding, and popularisation of Livonian heritage could be the creation of a Livonian cultural historical trail. This could pass through the Livonian villages and along the various sights associated with Livonian cultural historical heritage. There could be small informational displays, signs. Latvia has so many interesting and varied nature trails, why could there not also be a Livonian trail?

Dundaga Municipality could be the main driving force in making these suggestions a reality and coordinating the work of the various local governments. Its 2014-2030 development strategy emphasises that Dundaga Municipality has a special role in maintaining Livonian cultural heritage in the historical fishing villages and ensuring that Livonian identity can also be perceived in the environment - on signs, in names, cultural events, and education opportunities. Recently, the "Kolka Livonian Meeting House" was constructed with the help of the European Maritime and Fisheries Fund and it is set to be opened in the first half of 2019. The goal of its work is to keep Livonian identity alive in the ethnic Livonian territory on the coast of northern Courland by including Livonian cultural values, coastal traditions, and natural and historical heritage in modern tourism. It is hoped that the Livonian Meeting House will become a modern multi-functional centre, which will offer detailed insight into Livonian culture and history as well as 
other aspects of the tangible and intangible heritage of the Livonian Coast and will function as a museum, tourism information centre, and informal educational centre under a single roof. By cooperating with Livonian community organisations and local governments, the Livonian Coast could become the best place in the world to learn about Livonian heritage in the present day.

\section{Acknowledgements}

This study was supported by the Latvian Ministry of Education and Science research programme "Latvian language" (VPPIZM-2018/2-0002).

\section{Addresses:}

Valts Ernštreits

Livonian Institute

University of Latvia

Kronvalda Blvd 4-220, Riga

LV-1010

E-mail: valts.ernstreits@lu.lv,valts.ernstreits@ut.ee

Baiba Šuvcāne

Kolka's Livonian Centre

Zītari, Kolka,

Kolkas pag., Dundagas nov.,

LV-3275

E-mail: baibasuvcane@inbox.lv

\section{References}

Blumberga, Gundega, Renāte Blumberga, Baiba Damberga, and Valts Ernštreits (2017) Livonians. Lìvlizt. Rīga: Līvõd İt, Līvu (Lībiešu) savienība.

Blumberga, Renāte, Tapio Mäkeläinen, and Karl Pajusalu, eds. (2013) Lībieši. Vēsture, valoda un kultūra. Rīga: Līvõ Kultūr sidām.

Ernštreits, Valts (2011) Lībiešu rakstu valoda. Rīga: Latviešu valodas aǵentūra

Ernštreits, Valts (2017) Lìvõ kēll. Lìbiešsu valoda. Rīga: Latviešu valodas aǵentūra.

LB = Blumberga et al (2017). 
Šuvcāne, Baiba (2010) Senais lībiešu ciems Kolka. Rīga: Jumava.

Šuvcāne, Baiba (2012) Lībiešu krasta stāsti. Rīga: Jumava.

Šuvcāne, Baiba (2015) Sauc par Vaidi mūsu ciemu. Rīga: Lauku Avīze.

Šuvcāne, Baiba (2017) Lībiešu krasts. Rīga: Latvijas mediji.

Šuvcāne, Valda Marija (2002) Lībiešu ciems, kura vairs nav. Rīga: Jumava.

Šuvcāne, Valda Marija (2003) Lībiešu folklora. Rīga: Jumava.

Šuvcāne, Valda Marija (2006) Mazirbe - mazs ciems jūrmalā. Rīga: Jumava.

\begin{abstract}
Kokkuvõte. Baiba Šuvcāne, Valts Ernštreits: Liivi pärandi otsinguil Liivi rannal. 2018. aastal kanti liivi kultuuriruum Läti rahvusliku vaimse kultuuripärandi nimekirja, et järgnevalt viia see vastavasse UNESCO nimekirja. Artikli eesmärk on dokumenteerida liivi vaimse kultuuripärandi olukorda tänapäeval, seda eriti liivi keele ajaloolisel kasutusalal Kuramaa Liivi rannas. Praegu on Liivi rand visuaalselt märgistamata ala, mis on jagatud kolme omavalitsuse vahel. Halduslik killustatus kajastub ka teabe paigutamisel. Viitadel ja stendidel on kasutatud liivi keelt, kuid liivikeelse teabe kvaliteet vajab parandamist. Ehkki Läti keeleseaduses on sätestatud, et Liivi rannas on lubatud kohtade ja organisatsioonide nimetustes kasutada läti keele kõrval ka liivi keelt, ei ole tänaseni paigaldatud ühtegi ametlikku kakskeelset silti. Ka turismiettevõtjad on loiud liivi pärandi, sealhulgas liivi keele kaasamisega oma reklaaminfosse. Aktiivsemad on ühiskondlikud organisatsioonid, kelle korraldatud üritustel on Liivi rannas võimalik tundma õppida mitmekesist kohalikku kultuuripärandit ja kuulda liivi keelt, mis ühendab liivi kultuuriruumi erinevaid tahke.
\end{abstract}

Märksõnad: vaimne pärand, keele dokumenteerimine, keelekeskkond, keeleline maastik, liivi keel

Kubbõvõttõks. Baiba Šuvcāne, Valts Ernštreits. Līvõd rāndas līvõd pierāndõkst vỏtšõs. 2018. āigast lopāndõksõl Līvõd îlma sai kēratõd Lețmō Rov vaimliz pierāndõks nimkerrõ ja īrgiz en̦tš riek UNESCO nimkēra vōrțõ. Kēra nīžõb iḷ sīe, kui tẩdõl pandõb līvõd vaimli pierāndõks, ižkiz kēḷ, um tämpõ Līvõd rāndas. Tämpõ Līvõd rānda äb ūo riekmīen nä̉õb ja um jagdõd kuolm mōgõr vail. Se um nādõb ka tieut äbīdlimizõs lagtimizõs Līvõd rāndas. Šiltõd ja stendõd pẩl um kỗlbatõd ka līvõ kīeldõ, bet tieut kvalitētõ vỏlks tīemõst jo paŗīmõks. Sīel īž āigal, laz kil Lețmō Vald kīel pandõks kītõb, ku Līvõd rāndas kūožnimīs ja mūši nimīs lețkīel kūoral võib kôlbatõ ka līvõ kīeldõ, tämpiz sōñõ äb ūo tīedõd mitīdtõ kōdkēl̦iz šiltõ. Ka turism jeddõvõtājizt äb võrkõt tarmõ võimizt tundtõbõks sōdõ līvõd pierāndõksõks, ka līvõ kīelkõks. Täs jo kierdõd àt seḷtšõd - nänt suggimižis Līvõd rāndas võib nādõ setmiṇpūoḷizt kultūr pierāndõkst ja kūlõ līvõ kīeldõ, mis um Līvõd īlma arīdi īdõkubbõ palštiji element. 